\title{
A Survey of Four Indo-Pakistani Scholars' Perspectives on the Islam-Democracy Discourse
}

\author{
Tauseef Ahmad Parray
}

\section{Islam-Democracy Discourse in the Twenty-first Century: An Introduction}

In contemporary times, the relationship between Islam and democracy democracy and its Islamic heritage and the process of democratization in Muslim societies, and other related themes - is a hotly debated and discussed topic. Throughout the Muslim world - from South, Southeast and Central Asia to Middle East and North Africa - Muslim thinkers have undertaken the effort of working within and cooperating with existing political regimes and authorities - from republics, monarchies and authoritarian dictatorships to pluralistic and relativity homogeneous societies. With the desire for democratization, along with the continuing resurgence of Islam in a dynamic global context, the demand and desire for democracy is widespread.

Two of the major developments in the final decades of the twentieth century to present are "religious resurgence" and "democratization." The debate over democracy and democratization in the Muslim societies, its definition and fundamentals, has continued for a long time, but, as it has acquired an impetus in recent years, and this debate has become highly intensified.

The Muslim world at present is the most diverse in the forms of the political systems it employs. It has traditional and constitutional monarchies, dictatorships, Islamic republics, and secular and some liberal democracies - and due to the diverse interpretations of its laws and sources of law, Islam possesses intellectual and ideological resources that can provide justification for a wide range of governing models from monarchy to democracy.

Tauseef Ahmad Parray is a doctoral candidate in the Department of Islamic Studies at Aligarh Muslim University in Aligarh, India. He has written several reviews for The American Journal of Islamic Social Sciences. He is also a section editor for The Journal of Humanity and Islam in Malaysia and a book review member of The Muslim World Book Review, located in the United Kingdom. 
Notwithstanding this resource, on the on hand, Muslims have failed to produce a viable and substantial model of self-governance, and today, the Muslim world boasts a diversity of types of regimes - dictatorships and sham democracies in Egypt, Sudan, and Tunisia; a secular democracy in Turkey; monarchies in the Gulf; pluralistic democracies in Bangladesh and Malaysia; and an Islamic state (a sort of theo-democracy) in Iran. And due to the recent uprisings and revolutions in the Middle East - that is the "Arab Spring," which still continues to unravel so many possibilities and uncertainties in the Middle East - and some of them continue to be in a process of change (especially, Egypt, Libya, and Tunisia where recent uprisings and revolutions have resulted in changes in the forms of their governments and political systems). On the other hand, it is important to note that neither the Holy Qur'ān nor the Hadith and Sunnah prescribe any particular form of government or an elaborate constitutional theory. It is for Muslims of every period to discover the most suitable form of government to address their needs - on the condition that the form and the institutions they choose are in full agreement with the explicit, unequivocal Islamic laws (Sharī'ah).

In response to the later argument (that Muslims are free to devise the most suitable form of government) many scholars such as Abdul Rashid Moten (of Malaysia), Sayed Khatab (of Australia) and Muhammad Asad (born as Leopold Weiss in Austria, who later lived in Pakistan and Spain), and Hasan Yousefi Eshkevari (Iranian cleric, researcher, journalist, and reformist thinker), share almost similar views. For example, Eshkevari contends that "never in Islam has the act of governing been mandated as a function of religion"; government, instead, is a "purely human endeavor", and it is not possible to have one form and one type of government at all times, and is contextually dependent on the times and conditions. ${ }^{1}$

Muslim scholars vary in their views and opinions in discussing and debating this issue - that is, they belong to a broad spectrum of perspectives, ranging from the extremes of those who maintain that Islam requires a democratic system and/or that Islam is compatible with democracy. And it is further complicated by those who deny a connection between the two, and maintain that both are totally incompatible. A majority of scholars throughout the world favor the compatibility thesis; they are sincerely engaged in developing, defining, and establishing an authentic and viable Islamic democracy with the help of Islamic long-standing traditions and conceptualizations of $\operatorname{sh} \bar{r} \bar{a}$ (consultation), khilāfah (stewardship), ijmā' (consensus), and ijtihād (a new solution to a juridical problem) -especially shürā. In this direction, in the following pages, I present the arguments, 
views, opinions, and writings of four prominent (living) Muslim intellectuals of India and Pakistan who favor Islam-democracy compatibility. They all lay emphasis on the concept of $s h \bar{u} r \bar{a}$ as the main and basic foundation and source of democratic ethics in Islam.

It is well-known even to this day that there is not a single definition that can adequately account for the evolution of democracy and its development throughout history. It is equally true that although as a term democracy is universally accepted, but there is not a universally accepted concept, model, or form of democracy. Democracy has been described as an "essentially contested concept," and it has changed and developed in the shade of a variety of social, economic, and political development. It has meant different things to different peoples at different times - from ancient Greece to modern Europe and America, from direct to indirect democracy, from liberal to representative, and from parliamentary to constitutional.

In the discourse of the Islam-democracy relation, the questions generally raised are: Is democracy compatible with Islam? Is there any relation between Islam and democracy? And if they are compatible, and have relation with one another, then what elements are present in Islamic tradition in the service of democracy? (or what are the bases of democracy in Islam?)

The active discourse on democracy in Islam and the notion of democratic participation does not imply that the word democracy is a Qur'ānic term, explicitly explained in the Qur'ān or in the Sunnah. What it really means is that the Islamic heritage contains key concepts and values/principles that are the foundations for the Islamic perceptions of democracy and the notions or positive features and values that come with democracy are compatible with the Islamic teachings based on the Qur'ān and the Sunnah. These principles and many others are inherent in the Islamic political order - which, in all its dimensions, from the sociopolitical and economic to the legal and to international issues, is based on the concept of tawhid (montheism) and seeks its flowering in the form of a popular vicegerency (khilāfah), and operates through a mechanism of shürā (mutual consultation). It is supported by the principles of equality, freedom, public welfare, the rule of law, the protection of human rights, the accountability of the rulers, the transparency of political processes, and an overriding concern for justice. ${ }^{3}$

\section{Views of Four Living Indo-Pakistani Muslim Intellectuals on the Compatibility of Islam and Democracy}

This section presents the views of four Indo-Pakistani thinkers on the compatibility of Islam and democracy. They are: Asghar Ali Engineer (b. 1939) of India, Professor Khurshid Ahmad (b. 1932), Muhammad Khalid Masud (b. 1939), and Javed Ahmad Ghamidi (b.1951) of Pakistan. 


\section{Asghar Ali Engineer (March, 10, 1939, in Rajasthan, India)}

This Indian Islamic scholar, reformist-writer, and activist is internationally known for his work on liberation theology in Islam, and he also leads the Progressive Dawoodi Bohra Movement. Although the focus of his work is on (and action against) communalism and communal and ethnic violence in India and South Asia - and is an advocate of a culture of peace, non-violence and communal harmony - he has also contributed various articles to the theme of the relationship between Islam and democracy.

In his article, "Is Islam Compatible with Democracy and Modernity?", while answering the question, "Whether Islam and democracy are compatible?," Engineer says that it is true that Shürā and a modern representative democracy may not be exactly similar - however, the spirit of modern democracy and the Qur'ānic injunction to consult people is the same in spirit. New institutions keep on developing, and human beings, depending on their worldly experiences, keep on changing and refining these institutions. And in Engineer's ideal world, the concept of Shūrā would mean a "democratic process and [a] constitution of proper democratic institutions of which elections are a necessary requirement." The Qur'ānic text not only provides the concept of Shürā; equally important, it does not support even remotely any concept of dictatorship or authoritarianism. For him, Qur'ān (3:159) and Qur'ān (42:38) mean to submit to a "properly and democratically constituted authority."

In an another article, "On Absence of Democracy in the Muslim World" - after a discussion on the development of Islamic state and society by Prophet Muhammad (SAAS) in Medina - Engineer maintains that the Prophet had enjoyed an immense moral authority, but he never converted it into formal political power. He was succeeded by the Rightly Guided Caliphs who despite tremendous problems tried to follow the vision of Islam and always consulted Muslims before taking any important policy decision. Though formally, it was not a democratic society in the sense modern societies are, it was "democratic in spirit" during the first thirty years of the Rightly Guided Caliphs. The Umayyads, who became rulers after the first four caliphs, managed to capture power and converted "a proto-democratic society into a feudal hierarchical one." ${ }^{5} \mathrm{He}$ further states that the Islamic democracy that prevailed in the days of the Prophet and the four caliphs was not revived by succeeding regimes in the Arab world, as well as the non-Arab world (from the Umayyads, to the Abbasids, the Safavids, the Ottomans, and the Mughals) - these regimes were dynastic and had nothing to do with "elective principle," and thus an "Islamic political culture" became more and more "feudalized." 
In focusing light on present Muslim societies and the process of democratization therein, Engineer contends that presently Egypt has a semblance of democracy; however, it is also far from a "real democracy." Malaysia too has "limited democracy," and because there is no "real democratic freedom" in Malaysia, it is "semi-democratic semi-authoritarian" political set up. Furthermore, Indonesia remained for long under military rule and has now come under a "democratic spell," but it is presently undergoing a great political turmoil. Engineer's view is that it will take quite some time for democracy to stabilize in Indonesia because powerful vested interests are out to sabotage it in order to reestablish the previous dictatorship. ${ }^{7}$

Furthermore, regarding democracy and pluralism, in his "What I Believe," - revealing his beliefs, his views, and his ideology - he writes:

I strongly believe in pluralism and diversity. I believe that uniformity; be it of religious or political beliefs or of cultural practices, result only in suppressing human creativity. Human creativity can thrive only in the situation of freedom and diversity. Democratic freedom has meaning only if diversity is allowed to flower. Strict uniformity can, and often does, lead to fascism. A truly democratic society can be promoted only, and only if diversity is allowed to flower. I, therefore, believe in three 'ds'i.e. democracy, diversity and dialogue.

I believe that democracy, diversity and dialogue sustain and strengthen each other. If there is no diversity, there can be no democracy and if there is no dialogue, diversity cannot be strengthened. Dialogue is the very spirit of religious and cultural diversity. A genuine dialogue can be conducted only in the spirit of democracy. ${ }^{8}$

Furthermore, in his "Islam, Democracy And Violence," he states that it is not at all correct to say that Islam is incompatible with democracy, because Islam does not come in the way of democracy (because Islam is actually democratic in nature); it is dictators and monarchs who come in its way. The authoritarian societies negate all these and hence not democracy but monarchy and dictatorship is un-Islamic.

As the modern society is emphatic about human equality without any distinction, and human rights and gender equality are of great significance - and hence, democracy is the only way out for a Qur'ānic concept of a just society to be realized. Thus we must properly educate Muslim masses and prepare them for acceptance of democracy in Islamic world. They should be made aware that those who oppose democracy in the name of Islam are really serving certain vested interests rather than Islam. Islam is quite compatible with democracy. It is rather the interests of rulers of Muslim countries which are not compatible with democracy. ${ }^{9}$ 
Thus, Engineer believes in the democratic spirit of Islam as exemplified by the principle of shürā in the Qur'ān, or governance by mutual consultation. Furthermore, he thinks that a democratic form of government that strives to establish a just society that reflects the spirit of Islam - a spirit that supports all governments in their endeavors to safeguard the human rights of all peoples.

Engineer, reaches the conclusion that the absence of democracy in Muslim countries is not by means of an" account of Islamic teachings or incompatibility of democracy with Islam but due to host of factors political, historical and cultural," and in other place, he offers the same view: "It is thus social and economic [along with political and historical] conditions which are more responsible for lack of democracy in the Islamic world and not the Islamic teachings." 10

\section{Khurshid Ahmad (March 23, 1932, in Delhi, India)}

This prominent Islamic scholar - a revivalist thinker and spokesman of Islamic movements around the world and one of the prominent ideologues of the Islamic revival in the contemporary world, who has been increasingly involved internationally in the Islamic revivalism - is of the view that Islam does not admit any separation between the material, and the moral, and between the mundane and the spiritual, and Islam enjoins people to devote all their energies to the reconstruction of their lives on healthy foundations.

In his article, "Islam and Democracy: Some Conceptual and Contemporary Dimensions," Ahmad declares that the term democracy is both a philosophy and a form of organization. The term indicates a set of ideals and principles and a political system, a mechanism for governance and a politico-legal culture. ${ }^{11}$ In Islam: Its Meaning and Message, he states that democracy as a philosophy and democracy as a form of organization is not one and the same thing. In the form of organization, Islam has its own system of democracy, but as a philosophy, "the two, i.e. Islam and western democracy, are basically different, rather opposed to each other." 12 In a keynote address on "Economics, Islam, and Democracy" for the Center for the Study of Islam and Democracy in Washington, D.C. (April, 2000, and reproduced in its journal Muslim Democrat) - Ahmad, while discussing the many problematic assumptions at work in Western discussions of democracy, he pointed out the troubling aspects to the West's "shift from God to Man." He mentioned that whereas Islam is a spiritual experience, a dynamic tradition, and an historical movement that has existed for over fourteen hundred years, modern democracy is a political idea and movement that has existed only four hundred years. Ahmad 
- while stating that "Muslims want democracy, but not an imposed democracy" - also makes it clear that "Western ideas must not be 'explored' but rather discussed and voluntarily adopted by those who accept them. People should be free to express themselves and choose their future."13

In the same address, he also made it clear that on an operational level, there is little dividing democracy from Islam, but that some secular conceptions of democracy are antithetical to a Muslim's faith. ${ }^{14}$

According to Ahmad, the political system during period of the Prophet and the Rightly Guided Caliphate was based on two main principles - the rule of law and the equality of all before the law, and the supremacy of the Qur'ān and Sunnah, and the resort to ijtihad in matters not covered by these sources - he contends that Islam and Muslim Ummah brook no sympathy for arbitrary and authoritarian rule. Whatever arbitrary power reigns is more a product of colonialization and Westernization, not of Muslim ideals, history, and contemporary aspirations. Muslims have their own concept and tradition of democracy and people's participation that ensures just rule, consultative processes at all levels, respect for rights and dissent, the independence of the judiciary, and political co-cultural pluralism. He very rationally argues, In his article, "Islam and Democracy: Some Conceptual and Contemporary Dimensions," he insists that there is "no contradiction between Islam and the [real] essence of democracy" - that is, Islam and true democratization are two sides of same coin, and as such, "democratic processes and Islam would go hand in hand," because "Democratization is bound to be a stepping stone of Islamization. The fulfillment of Islamic aspirations would become possible only through promotion of democratic processes." 15

While describing the present striving of Muslims for the achievement of democratization, Ahmad claims that despite the freedom from the colonial yoke, the Muslim Ummah is still striving for its right - its democratic right to freely develop its polity, society, and economy in light of its own ideas, values, and aspirations:

It [the Muslim Ummah] refuses to live under the dictate of concepts and models in conflict with its faith, opposed to its values, distasteful to its history and repugnant to its traditions. If democracy means rights of a people to self-determination and self-fulfillment, that is what Islam and Muslims have been striving for, nothing more and nothing less. ${ }^{16}$

As I mentioned earlier that the concept of democracy is contested and there is no universally accepted model of democracy, so democracy remains a multi-faced phenomenon, both at the conceptual as well as operational level (that is, both in theory and practice). Within the context of Islamic faith, culture, history, and contemporary experience, Ahmad finds clear guidelines that suggest a unique and distinct political framework - 
one that can be described as truly participatory, both in substance and spirit; and one that can establish a political order committed to the twin goals of ' $a d l$ (justice) and shūrā, the real substance of operational democracy.

\section{Muhammad Khalid Masud (April 15, 1939, in East Punjab, Pakistan)}

This Pakistani scholar has had an enduring interest and an impact of social change on Islamic law - and his methodology, notably in its emphasis on context, in many respects, is similar to that of Fazlur Rahman (1919-1988). Masud has written extensively on pluralism, Muslim minorities, Islamic law, and other subjects. His views on democracy can be found in his article "Defining Democracy in Islamic Polity." 17

In the very beginning of his article, he asserts that broadly speaking, three views have emerged in the slam-democracy discourse: (1) often favored by the Western media, one view holds that Muslim societies are unable to develop a liberal culture, and hence, Muslim countries have not been able to achieve democracy; (2) a majority view among Muslim intellectuals claims that democracy is not only compatible with Islamic teachings but also that Islamic polities in history have been more democratic than any other system in the world; and (3) that democracy is a foreign Western concept and does not go along with Islamic teachings.

For Masud, thus, "Islamic democracy" (democracy defined from the Islamic perspective), differs from "Western" democracy in form as well as in objectives. Whatever the perspective, he claims that studies on Islam and democracy "never fail to stress the point that building democracy in Muslim countries is a formidable task." 18

In this essay, he analyzes four texts (articles and books) that illustrate these three broad views - namely, Martin Kramer's "Islam vs. Democracy" (1996); Khalifa Abdul Hakim`s The Prophet and his Message (1987); Amin Ahsan Islahi`s Islami Riyasat [Islamic State] (1977), and Qari Tayyib`s, Fitri Hukumat [Natural State] (1963). By means of this analysis, Masud explores the question: why building democracy is such a formidable task?

Martin Kramer contends that Islam is the reason that so many Muslim countries are not democratic. He seems to have taken a very difficult position: that Muslims cannot be democratic unless they give up Islam. For him, majority opinion, elections, and the participation of the masses do not count as the ingredients of democracy. ${ }^{19}$

Khalifa Abdul Hakim maintains that the question about the compatibility of democracy to Islam continues to be problematic - not because 
Islam is not favorable, but because democracy is not definable. For him, democracy is problematic to define in the West and in the Muslim world as well. He concludes that Islam's original vision calls for democracy. ${ }^{20}$

In his book Natural State, Qari Tayyib states that the government on earth is a khiläfat (deputy of God), which establishes a system of government on the pattern of the natural state of the Divine. The Islamic caliphate is distinct from all other systems because in these systems humans assume the authority of the Divine. The Islamic system of government also differs from others in the following aspects: "Imaret (leadership, government), without Shura is tyranny (istibdad) and [abriyyat] dictatorship, and Shura without Amir [leader] is anarchy (fawdawiyyat) and de-centrism (la markaziyyat). In its most excellent form of a comprehensive and moderate religion, Islam combines autocracy and democracy . . . Consequently, an Islamic government combines autocracy and democracy, neither is autocracy independent of democracy, nor is democracy independent of autocracy,"21

To Amin Ahsan Islahi, an Islamic state (khiläfat) does not differ much from an ordinary state in its formal and material structure (population, territory, internal independence, political institution); it differs in principles and objectives. Khiläfat means complete equality; it is not limited to a class or person. However, he regards both the parliamentary and presidential systems, as being currently in vogue and against Islam. Muslims have a limited right to legislate in such matters in which are not clearly given insight from passages in the Qur'ān or guidance from the Sunnah. The folowing is Islahi's position on the people in an Islamic state:

In a secular (la dini) democratic state (Jamhuri riyasat), sovereignty (hakimiyyat) belongs to the people. But . . . in an Islamic state sovereignty belongs to God. Islamic state is not a democratic nation-state (qawmi riyasat) in which every inhabitant in the country is assumed to be a partner in the sovereignty. It is rather an ideological (usuli) state. . . . Sovereignty does not belong to even these Muslim people (Jamhur Muslimin). They have authority only to apply the Divine law (Shari'ah), and to form a political system within the laws and the limits prescribed by God.22

After examining and analyzing the views of these four scholars/writers, Masud says that in defining democracy in the Islamic polity, the scholars seem to focus on the "Rule of law, equality, freedom, liberty right to vote, elections, party system, parliamentary system, legislative authority, a state's right to legislate, forms of government, and sovereignty." Although most writers speak about the participation of the people or masses in the governance, and some even speak of the sovereignty of the people, but the real problem is the "recognition of the role, place and right of a common man in government." 23 
In his view, the real issue in defining democracy is the place and value assigned to the common man as an individual - something not yet fully developed in the present political systems. He concludes that in spite of the emergence of democracy in the Western systems, the concept is still in the making. The main problem is the "fundamental paradigm shift" in political thinking. Consequently, the emphasis on the role of masses in present political systems is not yet fully developed. ${ }^{24}$

Javed Ahmad Ghamidi (April 18, 1951, Punjab City, Pakistan):

Javed Ahmad Ghamidi extended the work of his tutor, Amin Ahsan Islahi (1904-1997) - an Indian/Pakistani exegete of the Qur'an, famous for his Urdu exegeses of the Qur'ān, Tadabbur-i-Qur'an. Ghamidi is frequently labeled a modernist for his insistence on the historical contextualization of Prophet Muhammad's revelation in order to grasp its true moral import. Ghamidi, who has been from the beginning opposing Islamism, states in "Islam and the Taliban":

The Taliban says that democracy is a concept alien to Islam. The ideal way of setting up an Islamic government in our times is the one that it adopted for Mullah Omar's government in Afghanistan. The constitution, the parliament, and elections are nothing but modern day shams. . . . I can say with full confidence on the basis of my study of Islam that this viewpoint and this strategy [of Taliban] are not acceptable to the Qur'an. It prescribes democracy as the way to run the affairs of the state. The Qur'an (42: 38) says: amruhum Shura baynahum (the affairs of the Muslims are run on the basis of their consultation). ... It is true that, in Muslim history, monarchy and dictatorship have often been accepted forms of government. Some people also believe that the head of government should be a nominee of God Himself. However, the principle the Qur'an spells out is very clear ${ }^{25}$

In "The Political Law of Islam," Javed Ahmad Ghamidi maintains that in the Qur'ān (42:38), the system of government of an Islamic state is based upon amruhum shürābaynahum (their affairs of state are run by their mutual consultation). He states that the style and pattern of this verse demands that even the head of an Islamic government should be established and maintained through consultation with the believers and should conduct its affairs in all cases on the basis of a consensus or the majority opinion of the believers. ${ }^{26}$

$\mathrm{He}$ even goes further:

Since, in our consideration the collective affairs of the Muslim are based on the Qur'anic [42:83] injunction: amruhum shūrā bainahum, 
the election of their ruler as well as their representatives must take place through consultation. Also, after assuming a position of authority they will have no right to overrule a consensus or a majority opinion of the Muslims in all the collective affairs. ${ }^{27}$

The previous quotation states that the Prophet, being divinely appointed, has an exception to this rule. However, in the Qur'ān (3:159), he too has been directed to consult others. It has been clearly stated that whatever opinion he forms after consultation, he should strictly adhere to it and rely totally on the Almighty: "Keep consulting in the affairs of state; then when you take a decision, put thy trust in Allah" (3:159). Regarding this interpretation, Ghamidi writes:

The above directive of the Qur'an [3:159] is in accordance with human nature and in harmony with all norms of common sense. No Muslim can be free of faults and shortcomings. He can be the most distinguished as far as piety and knowledge are concerned; he can be the most suitable for the position of authority he holds and can even consider himself so. With these abilities also, he cannot attain the position of Khilafat without the general opinion of the Muslims. ${ }^{28}$

In The Political Shari ah of Islam, one of Ghamidi's the main conclusions - that shows both his position regarding the place of democracy in Islam as well as his belief about the Islamic form of government - is summarized as: "the form of government envisaged by Islam is neither a theocracy nor a monarchy. It is more akin [and similar] to democracy as a Muslim government comes into existence on the basis of a public mandate and continues to exist as long as it commands the support of the majority." 29

\section{Conclusion:}

By way of conclusion, the following becomes clear:

1. There may be, at least in theory, a number of ways and methods for increasing the participation of the people in government, but the most widely accepted way of expressing these desires is the demand for democracy and Muslims - relying upon of a number of important concepts and values (from within the Islamic heritage), especially of shüra (mutual consultation) - are trying to lay the foundations for the Islamic perceptions of democracy; and

2. From the last few decades, the most widely accepted way to increase the people's participation in government, is the demand for democracy. And while utilizing and reinterpreting several 
important concepts and values from within the Islamic heritage, modernist Muslims intellectuals are trying to lay the foundations of a political order that harmonizes Islamic principles with a democratic system of government.

Furthermore, the two Qur'ānic verses quoted above (3:159 and 42:38) express clearly the view that an Islamic government cannot help but be consultative, democratic, and divinely inspired. Lastly, I contend (and emphasize) that with more reflection (manifestation and evidence) and research (investigation and exploration), reinterpretation is required to reconcile the tenets of Islam with the modern notions of democracy, liberty, justice, equality, and human rights - as the Islamic primary sources, the Qur'ān and the Sunnah, throw ample light and guidance on these concepts and values.

\section{Endnotes:}

1. Hasan Yusofi Eshkevari, "Hokumat-e Demokratik-e Eslami" (Democratic Islamic Government), in Ali Muhammad Izadi et al., Din va Hokumat (Religion and Government) (Tehran, Iran: Rasa, 1377/ 1998), 299, 300; Mehran Kamrava, "Shi'ism at the Gates of Historic Change," in Innovation in Islam: Traditions and Contributions, ed. Mehran Kamrava (Berkeley, CA: University of California Press, 2011), 61

2. W. B. Gallie, Philosophy and the Historical Understanding (London: Chatto and Windus, 1964), 158

3. These ideas are borrowed from Sayed Khattab and Gary D. Bouma, Democracy in Islam (London and NY: Routledge, 2007); John L Esposito and John O. Voll, Islam and Democracy (NY: Oxford University Press, 1996); and Khurshid Ahmad, "Islam and Democracy: Some Conceptual and Contemporary Dimensions," The Muslim World, 90 (2000): 1-21.

4. Asghar Ali Enginner, "Is Islam Compatible with Democracy and Modernity?", in Engineer, Islam: Challenges in $21^{\text {st }}$ Century (New Delhi, India: Gyan Publishing House, 2004), 213-14.

5. Engineer, "On Absence of Democracy in the Muslim world", in Engineer, On Developing Theology of Peace in Islam (New Delhi. India: Sterling Publishers Pvt Ltd., 2003), 82.

6. Ibid. $86-87$

7. Ibid. 88-89.

8. Asghar Ali Engineer, “WHAT I BELIEVE”, http://andromeda.rutgers. edu/ rtavakol/engineer/belief.htm. Italics have been added for emphasis. 
9. Asghar Ali Engineer, 'Islam, Democracy and Violence' available on Indian Muslims, http://indianmuslims.in; or http://indianmuslims.in/ islam-democracy-and-violence/.

10. Engineer, Islam: Challenges in $21^{\text {st }}$ Century, 214; Engineer, On Developing Theology of Peace in Islam, 89. Italics have been added for emphasis.

11. Ahmad, "Islam and Democracy," The Muslim World, 3

12. Khurshid Ahmad, ed., Islam: Its Meaning and Message, (New Delhi, India: Ambika Publications, on behalf of The Islamic Council of Europe, London 1976), 160n24.

13. Khurshid Ahmad, Key Note Address on "Economics, Islam, and Democracy," The Center for the Study of Islam and Democracy April, 2000; reproduced in Muslim Democrat, 2, no. 2, (June 2000): 5,7 - www.csidonline.org/documents/pdf/md_june00.pdf.

14. Ibid. 7

15. Ahmad, "Islam and Democracy,", The Muslim World, 19

16. Ibid. 20. Italics have been added for emphasis.

17. M Khalid Masud, "Defining Democracy in Islamic Polity" (paper presented in the International Conference on The Future of Islam, Democracy, and Authoritarianism in the Era of Globalization,, organized by the International Centre for Islam and Pluralism, Jakarta, December 5-6, 2004. Available at www.maruf.org/?p=69.

18. Ibid.

19. Martin Kramer, "Islam vs. Democracy," Commentary Magazine, January 1993, 35--42. This is the version revised for republication in Martin Kramer, Arab Awakening and Islamic Revival (New Brunswick, NJ: Transaction Publishers, 1996), 265-78. Available at www.martinkramer.org/sandbox/reader/archives/islam-vsdemocracy/.

20. Khalifa Abdul Hakim, The Prophet and His Message (Lahore, Pakistan: Institute of Islamic Culture,1987).

21. Qari Tayyib, Fitri Hukumat (Lahore, Pakistan : Idara Islamiyyat, 1963), 220

22. Amin Ahsan Islahi, Islami Riyasat (Lahore, Pakistan : Anjuman Khuddamul Qur'an, 1977), 21

23. Masud, "Defining Democracy in Islamic Polity."

24. Ibid.

25. Javed Ahmad Ghamidi, "Islam and the Taliban", (Tr. by: Asif Iftikhar) , in Renaissance 19, no. 6 (June 2009), www.monthly-renaissance. com/issue/content.aspx?id=1158. Italics have been added for emphasis. 
26. Javed Ahmad Ghamidi, "The Political Law of Islam," trans. Shehzad Saleem. Renaissance, www.monthly-renaissance.com/issue/content. aspx?id=987. Italics have been added for emphasis.

27. Ibid.

28. Ibid.

29. Javed Ahmad Ghamidi, The Political Shari'ah of Islam, trans. by Shehzad Saleem, (Lahore, Pakistan: Al-Mawrid Foundation of Islamic Research and Education, n.d.), 2, www.monthly-renaissance. com/issue/content.aspx?id=987. 